\title{
キクの花芽分化抑制における暗期中断電照の波長の影響
}

\author{
白山竜次 ${ }^{1 *} \cdot$ 永吉実孝 $^{2}$ \\ 1 鹿児島県農業開発総合センター花き部 891-0513 鹿児島県指宿市山川岡児ヶ水 \\ 2 鹿児島県バイオテクノロジー研究所 893-1601鹿児島県鹿屋市串良町細山田
}

\section{Effects of Night-break Light Quality on Floral Inhibition of Chrysanthemum}

\author{
Ryuji Hakuzan ${ }^{1 *}$ and Sanetaka Nagayoshi ${ }^{2}$ \\ ${ }^{1}$ Kagoshima Prefectural Institute for Agricultural Development Flower Section, Ibusuki, Kagoshima 891-0513 \\ ${ }^{2}$ Kagoshima Biotechnology Institute. Kanoya, Kagoshima 893-1601
}

\begin{abstract}
Effects of the wavelength of night-break light on the inhibition of flower bud differentiation in chrysanthemum were investigated using the cultivars 'Arajin2' and 'Iwanohakusen'. Wavelengths of 516, 593, 630, 663, 684, and $705 \mathrm{~nm}$ of light were produced using LED lamps. Effective wavelengths for inhibition in both 'Arajin2' and 'Iwanohakusen' were 593, 630, and $663 \mathrm{~nm}$, and the most effective wavelength was $630 \mathrm{~nm}$ in 'Arajin2' and 593 and $630 \mathrm{~nm}$ in 'Iwanohakusen', respectively. The effectiveness of red light or a mixture of red and far-red light as a night-break light was compared using 'Arajin2' and 'Iwanohakusen'. No difference in the inhibition of flower bud differentiation was observed in 'Arajin2', whereas the mixed light of red light and far-red light was more effective than red light to inhibit flower bud differentiation of 'Iwanohakusen'.
\end{abstract}

Key Words : far-red right, LED, phytochrome, red right

キーワード : 遠赤色光, フィトクロム, LED, 赤色光

\begin{abstract}
緒 言
ガーナーとアラードが植物の日長反応を発見して 1 世紀 近くが経過している．日長を人為的に調整することによる 開花調節は，多くの花き栽培で実用技術となっている（久 松, 2011). キクは短日植物で, 短日期に電照による長日処 理を行らことで，人為的に花芽分化を抑制し，開花時期の 調整や草丈の確保を行っている. この電照栽培によりキク は周年出荷を実現して抢り, 日長制御はキク栽培の基盤技 術のひとつである.

キク電照栽培用の光源はこれまで白熱電球が中心であっ たが，省エネルギー対策による代替光源への移行推進の動 きから，ここ数年で蛍光灯や発光ダイオード（LED）への 移行が進みつつある. 蛍光灯や LED ランプは, 白熱電球に 比較して電気エネルギー光変換効率が高く, 同等の照度 (明 るさ）を確保する場合, 消費電力が低く寿命も長い。 また 蛍光灯やLED ランプは蛍光体や半導体材料を変えることに より光質の変更が可能であり, 特に LED ランプは様々な単
\end{abstract}

2012 年 3 月 13 日 受付. 2012 年 10 月 23 日 受理.

本研究の一部は, 新たな農林水産政策を推進する実用技術開発 事業「今こそチャレンジ! 国産花きの周年効率安定生産システ 么の構築（課題番号 2007）」において行われた。

* Corresponding auther. E-mail: hakuzan@pref.kagoshima.lg.jp
一ピーク波長の光照射が得られる点が大きな特長となって いる.しかしながら現場では，光質と花芽分化抑制効果に ついて十分な検討がなされないまま，昼光色や電球色，赤 色などの光質の異なる蛍光灯や赤色光でも波長の異なる LED ランプが導入されているのが現状である.

植物の日長反応において光情報センサーのひとつとして 働くフィトクロムは, 光発芽, 脱黄化, 避陰反応, 光周性 などの様々な生理反応を制御していることが知られている (Borthwic 5，1952a, 1952b). フィトクロムは $660 \mathrm{~nm}$ また は730 nm にピークを示す異なる二型の吸収スペクトルを 可逆的に示す色素タンパク質で，赤色光（以下， R 光と記 す）を吸収する Pr 型と遠赤色光（以下，FR 光と記す）を 吸収する Pfr 型が存在し, Pr 型は生理的に不活性で Pfr 型 が生理的な活性を示す.Pfr 型はFR 光の照射や暗黒条件で Pr 型へと変化し, Pr 型は R 光により Pfr 型に変化する可逆 性を示すことが知られている．また短日植物の花芽分化抑 制に有効な暗期中断時の波長は，概ね $600 \sim 700 \mathrm{~nm}$ の R 光とされて扣り（Borthwic ら，1948, 1952a; Parker ら，1946, 1950), 暗期中断処理では R 光の効果は FR 光が打ち消すた め, R/FR 比の高い光源が花芽分化抑制効果が高いとされて いる（Cathey・Borthwick, 1964）。近年，ゲノム情報の明ら かになったシロイヌナズナとイネでは，それぞれ 5 種類 (phyA-E), 3 種類 (phyA-C) のフィトクロム分子種が存在 
することが明らかになり, 変異体を用いた機能解析が精力 的に行わ玌ている. イネでは, 暗期の中央での光中断処理 によって花成ホルモンをコードする heading date $3 a(h d 3 a)$ 遺伝子の発現が抑制され，この時，phyBが重要な役割を 担っていることが示されている (Ishikawa ら，2005).

LED ランプは，採用する LED チップにより光質を選べ るといら特徴がある反面, どの波長帯の LED チップを用い れば最も効率的な電照用光源になるかといら問題が新たに 提起されている．LEDを用いた試験（石倉ら，2009）では $\mathrm{R}$ 単色光が光中断用光源として白熱電球と同等に有効であ ること, 花芽分化抑制効果のある黄色 LED 光をパルス照射 すれば抑制効果を回避できること（石倉ら，2010）が報告 されている。しかしながら最近まで, 圃場環境において単 一ピーク波長の分光特性を有するLED光源の利用が困難で あったため，キクの電照に打ける光源の波長と花芽抑制効 果を詳細に調べた報告は少なく，また秋ギクと夏秋ギクを 同一波長の光源を用いて比較検討した報告は見当たらな い.また FR 光は $\mathrm{R}$ 光の作用を打ち消すとされているもの の, 現場では品種によっては FR 光の多い白熱電球よりも FR 光の少ない蛍光灯の方が電照の効きが劣るといった事 例もあり, 著者らが行った夏秋ギク ‘岩の白扇’ の電照比 較試験でも $\mathrm{R} / \mathrm{FR}$ 比 9.0 の $23 \mathrm{~W}$ 三波長型電球色蛍光灯は $\mathrm{R} /$ FR 比 0.7 の $75 \mathrm{~W}$ 白熱電球に比較して花芽抑制効果が劣っ た（未発表）. FR 光の花芽分化に及活す影響については, 鈴木ら（2011），渡辺ら（1996）の報告があるが，いずれも $\mathrm{R}$ 光に FR 光を加えることで, 花芽分化抑制の効果が低下 するような結果は得られていないなど, 従来の知見とは異 なった結果が生じているため, キクの花芽分化抑制に対す る $\mathrm{R}$ 光と FR 光の関係については, 試験手法も含めて再度 検証する必要がある. 現場では蛍光灯を中心に白熱電球代 替光源の導入が進んでいるが, 白熱電球に比較して波長特 性が異なるために，これまで電照抑制の指標とされてきた 照度が使えない, 従って光源が異なると花芽分化抑制能力 の評価が難しいなぞの課題が生じている. 電照抑制の効果 を異なる光源で評価する場合は，キクの花芽分化抑制に有 効な波長の応答曲線を作成することで, 異種光源でも花芽 分化抑制能力の検定が可能になり，キク電照用光源の開発 にも寄与できると著者らは考学る，そのためには，花芽分 化抑制に効果が高いと言われている R 光を中心とした波長 域の応答感度と, $\mathrm{R}$ 光照射に及ぼす $\mathrm{FR}$ 光同時照射の影響 について調べる必要がある。

そこで本試験ではキクの効率的な電照抑制技術開発のた めに, ピーク波長の異なる数種類の電球形 LED ランプを用 いて，暗期中断時に打けるピーク波長 $516 \mathrm{~nm}$ の緑色光〜 $705 \mathrm{~nm}$ の FR 光までの単一ピーク波長照射が花芽分化抑制 効果に及活す影響を明らかにするとともに, $644 \mathrm{~nm}$ の R 光 照射時に打ける $732 \mathrm{~nm}$ の FR 光同時照射の花芽分化抑制効 果に及ぼす影響について検討を行った。

\section{材料および方法}

\section{1. 光源}

本試験に供試した電球形 LED ランプ（試作品，エルム） の特性を第 1 表，第 2 表，第 1 図（試験 $1 ， 2 ）$ 拈よび第 3 表, 第 2 図（試験 3，4）に示した. 試験 1，2 とは，ピー ク波長 516，593，630，663，684 抢よび $705 \mathrm{~nm}$ の緑〜暗 赤色の 6 種類の電球形 LED ランプを用いた. 試験 3 および 4 では，ピーク波長 $644 \mathrm{~nm}$ の R 光とピーク波長 $732 \mathrm{~nm}$ の FR 光の 2 種類を用いた. LED ランプのピーク波長は, LED チップのカタログ記載の公称ピーク值 $\pm 10 \mathrm{~nm}$ 程度の䛊差 がある.このため本試験では実際に使用した電球形 LED ラ ンプで計測したピーク值を以下の結果と考察で用いた．各 LED チップの波長測定は分光放射照度計 MS-720（ハロゲ ン補正済み，英光精機）を使用した，試験 1 および 2 に供 試した電球形 LED ランプの全放射束は積分球を用いて $200 \mathrm{~mW} \cdot \mathrm{m}^{-2}$ 亿調整を行った。試験 3 打よび 4 亿用いた LED 光源は全放射束の調整を行わなかったため, 各光源の 畦面に打㳊射照度を測定し第 3 表に示した．放射照度 の測定は放射照度計 HD2102.2（放射照度測定プローブ LP471RAD，測定波長域 $400 〜 1050 \mathrm{~nm}$ ，Delta OHM）を使

第 1 表 試験 1 ・ 2 亿供試した光源の特性一覧

\begin{tabular}{ccccc}
\hline \hline $\begin{array}{c}\text { ピーク波長 } \\
(\gamma \mathrm{P})\end{array}$ & $\begin{array}{c}\text { ピーク波長 } \\
(\gamma \mathrm{P})\end{array}$ & $\begin{array}{c}\text { 全放射束 } \\
(\mathrm{mW})\end{array}$ & $\begin{array}{c}\text { スペクトル } \\
\text { 半值全幅 } \\
(\text { (公称値 } \mathrm{nm})\end{array}$ & $\begin{array}{c}\text { 光色 } \\
\text { (実測値 } \mathrm{nm})\end{array}$ \\
\hline 530 & 516 & 201 & 37 & 緑 \\
590 & 593 & 191 & 14 & 橙 \\
625 & 630 & 185 & 15 & 赤 \\
660 & 663 & 201 & 12 & 赤 \\
680 & 684 & 218 & 24 & 暗赤 \\
700 & 705 & 188 & 25 & 暗赤 \\
\hline
\end{tabular}

第 2 表 試験 $1 ・ 2$ 飞供試した光源の放射照度 $50 \mathrm{~mW} \cdot \mathrm{m}^{-2}$ 時 に扣汀る光量子束密度

\begin{tabular}{cc}
\hline \hline ピーク波長 $(\gamma \mathrm{P})(\mathrm{nm})$ & 光量子束密度 $\left(\mu \mathrm{mol} \mathrm{m}^{-2} \mathrm{~s}^{-1}\right)$ \\
\hline 516 & 0.220 \\
593 & 0.249 \\
630 & 0.262 \\
663 & 0.274 \\
684 & 0.284 \\
705 & 0.292 \\
\hline
\end{tabular}

第 3 表 試験 $3 ・ 4$ 亿供試した光源の放射照度 $\left(\mathrm{mW} \cdot \mathrm{m}^{-2}\right.$ 畦 面実測値) ${ }^{\mathrm{z}}$

\begin{tabular}{lcc}
\hline \hline & $644 \mathrm{~nm} \mathrm{LED}$ & $732 \mathrm{~nm} \mathrm{LED}$ \\
\hline $\mathrm{R}$ 光照射区 & 160.9 & 0 \\
$\mathrm{R}+\mathrm{FR}$ 光照射区 & 158.8 & 94.1 \\
\hline
\end{tabular}

${ }^{\mathrm{z}}$ 放射照度計 HD2102.2（Delta OHM）飞よる測定

${ }^{\mathrm{y}}$ 分光放射照度計 MS-720 によるピーク波長実測値 




第 1 図試験 1,2 に供試した LED ライトの波長特性

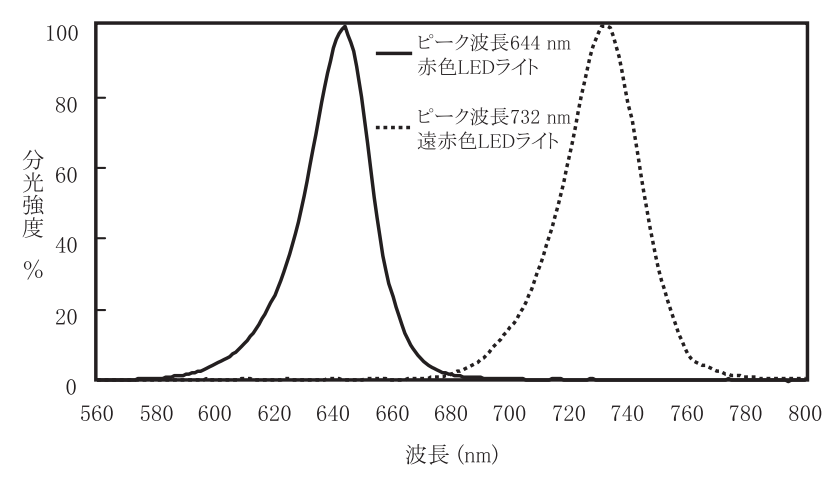

第 2 図試験 3, 4 に供試した赤色 LED ライトと遠赤色 LED ライトの波長特性

用した．な执，植物の光応答は基本的には光量子反応と考 えられて扔り, 照射する光量については光量子束密度で表 記することが一般的であるが，本論文では測定器具の入手 性や現場での利用なぞを考慮して放射照度で記載したが， 参考までに第 2 表に各 LED に抢汸放射照度 $50 \mathrm{~mW} \cdot \mathrm{m}^{-2}$ のときの光量子束密度を表示した.

\section{2. 単波長光源の花芽分化抑制能力の検討}

1) 夏秋輪ギク ‘岩の白扇’ における波長と抑制効果 (試験 1) 夏秋系白輪ギク ‘岩の白扇’を供試した。試験は単棟の ビニルハウスを用い, 畦面の放射照度は予備試験の結果よ り，光質による花芽分化抑制効果の差が現れると考光られ た $50 \mathrm{~mW} \cdot \mathrm{m}^{-2}$ に設定した. 定植は 2010 年 4 月 23 日に行 い, 定植後から 6 月 20 日（栄養成長期間； 58 日間）まで 暗期中断 5 時間（22:00〜3:00）電照をピーク波長の異な る 6 種類の電球形 LED ランプを用いて行った. 成長につれ て成長点付近の光量が高くなるため, 成長点付近の放射照 度を 5 月 21 日に $50 \mathrm{~mW} \cdot \mathrm{m}^{-2}, 6$ 月 2 日に $70 \mathrm{~mW} \cdot \mathrm{m}^{-2}$ に なるよらに光源の設置高さを変えて調整した。電照は各区 の発蕾を確認してから消灯した. 栽植様式は床幅 $90 \mathrm{~cm}$ に $15 \mathrm{~cm} \cdot 6$ 目ネットを用いて, 一目当たり 2 本植えとし中央 2 列を空けて (2-2-0-0-2-2) 定植した. 施肥は基肥 $\mathrm{N}: \mathrm{P}_{2} \mathrm{O}_{5}$ : $\mathrm{K}_{2} \mathrm{O}=24: 16: 16\left(\mathrm{~kg} \cdot 10 \mathrm{a}^{-1}\right)$ であった. 調査は光源直下 付近の 20 株について, 区全体の 50\%発蕾日と各個体の展 開葉数を調査した.

\section{2）秋輪ギク ‘新神 2’における波長と抑制効果（試験 2)}

‘新神 2’は秋輪ギク ‘神馬’を由来として突然変異手法 を用いて育成された品種である（永吉ら，2010）。供試種苗 の母株栽培はビニルハウスで電球形蛍光灯による暗期中断 4 時間電照で行った。 また育苗はガラスハウスで電球形蛍 光灯による暗期中断 5 時間電照で行った。試験は硬質プラ スチックハウスを用いた。 定植は 2010 年 9 月 6 日に行い, 定植後 10 月 27 日（栄養成長期間 ; 51 日間）まで暗期中 断 5 時間（22:00〜3:00）電照を行った. なお，植付け後 10 日間は, 苗の活着むらなどの影響を考慮して, すべての 区で白熱電球による電照を行い, 11 日目からそれぞれ 6 種 類の電球形 LED ランプに付け替えて処理を開始した. 光量 は畦面の放射照度が $50 \mathrm{~mW} \cdot \mathrm{m}^{-2}$ になるように，各光源の 高さを調整し, その後の調整は行わなかった，電照は各区 の発蕾を確認してから消灯した。栽植様式は試験 1 と同様 とした. 調查は光源直下付近の 30 株について, 区全体の $50 \%$ 発蕾日と各個体の展開葉数を調査した.

\section{R 光および $F R$ 光の組み合わせによる花芽分化抑制能力 の検討 \\ 1）夏秋輪ギク ‘岩の白扇’における比較試験（試験 3）}

試験はガラス八ウスを用いた。育苗掞よび栽植様式は試 験 1 と同様とした。定植は 2010 年 5 月 21 日に行い, 定植 後〜 7 月 10 日（栄養成長期間； 50 日間）まで 2 種類の電 球形 LED ランプにより暗期中断 5 時間（22:00〜3:00）電 照を行った。本試験で使用した $644 \mathrm{~nm}$ 赤色電球形 LED ラ ンプはキク電照栽培用に開発されたもので, 畦面に打ける 放射照度は概衸 $160 \mathrm{~mW} \cdot \mathrm{m}^{-2}$ で, 本試験用に試作した $732 \mathrm{~nm}$ FR 電球形 LED ランプの畦面に扮ける放射照度は $94 \mathrm{~mW}$ ・ $\mathrm{m}^{-2}$ であった (第 3 表). 調査は電照直下の 40 株について, 消灯時预よび開花時の草丈と展開葉数を調查した.

\section{2）秋輪ギク ‘新神 2’における比較試験（試験 4)}

試験はガラス八ウスを用いた。育苗および栽植様式は試 験 2 と同様とした．定植は 2010 年 9 月 22 日に行い, 定植 後〜 11 月 9 日（栄養成長期間； 47 日間）まで 2 種類の電 球形 LED ランプにより暗期中断 5 時間（22:00〜3:00）電 照を行った. 暗期中断の光量については試験 3 と同等であっ た. 調査は電照直下の 22 株を選び, 消灯時および開花時の 草丈と展開葉数を調査した.

\section{結 果}

\section{1. 単波長光源の花芽分化抑制能力の検討}

1）夏秋輪ギク ‘岩の白扇’における波長と抑制効果（試験 1) 暗期中断光源の波長の違いによる花芽分化抑制効果は 発蕾日と開花時の展開葉数で判定した. すべての区で電照 期間中に発蕾が認められた。発蕾日は, 無処理区と 516, 684 抢よび $705 \mathrm{~nm}$ 区が泳涪同等で最も早く, 次いで 663, 593 および $630 \mathrm{~nm}$ 区の順であった。展開葉数は無処理区 と 516, 684 扣よび $705 \mathrm{~nm}$ 区が 32 枚と最も少なく, 次い で $663 \mathrm{~nm}$ 区が 36 枚，593，630 nm 区で約 40 枚と最も多 
第 4 表 暗期中断照明の波長が, 夏秋輪ギク ‘岩の白扇’ の花 芽分化抑制に及ぼす影響

\begin{tabular}{ccc}
\hline \hline $\begin{array}{c}\text { ピーク波長 }(\gamma \mathrm{P}) \\
\text { (実測值 } \mathrm{nm})\end{array}$ & $\begin{array}{c}\text { 発蕾日 } \\
(\text { 月 } / \text { 日) }\end{array}$ & $\begin{array}{c}\text { 展開葉数 } \\
\text { (枚) }\end{array}$ \\
\hline 無電照 & $5 / 26$ & $31.2 \mathrm{a}^{\mathrm{z}}$ \\
516 & $5 / 26$ & $32.3 \mathrm{a}$ \\
593 & $6 / 7$ & $39.4 \mathrm{c}$ \\
630 & $6 / 7$ & $40.8 \mathrm{c}$ \\
663 & $6 / 4$ & $36.3 \mathrm{~b}$ \\
684 & $5 / 26$ & $32.2 \mathrm{a}$ \\
705 & $5 / 25$ & $31.6 \mathrm{a}$ \\
\hline
\end{tabular}

z 異なる文字間については, Tukey-kramer 法により 5\%水準 で有意差あり

第 5 表 暗期中断照明の波長が, 秋輪ギク ‘新神 2’ の花芽分 化抑制に及ぼす影響

\begin{tabular}{ccc}
\hline \hline $\begin{array}{c}\text { ピーク波長 }(\gamma \mathrm{P}) \\
\text { (実測值 } \mathrm{nm})\end{array}$ & $\begin{array}{c}\text { 発蕾日 } \\
(\text { 月 } / \text { 日) }\end{array}$ & $\begin{array}{c}\text { 展開葉数 } \\
(\text { 枚 })\end{array}$ \\
\hline 無電照 & $10 / 5$ & $38.6 \mathrm{a}^{\mathrm{z}}$ \\
516 & $10 / 6$ & $40.4 \mathrm{a}$ \\
593 & $10 / 11$ & $49.2 \mathrm{c}$ \\
630 & $10 / 26$ & $60.2 \mathrm{e}$ \\
663 & $10 / 17$ & $52.5 \mathrm{~d}$ \\
684 & $10 / 7$ & $43.5 \mathrm{~b}$ \\
705 & $10 / 7$ & $42.9 \mathrm{~b}$
\end{tabular}

z 異なる文字間については，Tukey-kramer 法により 5\%水準 で有意差あり

第 6 表 $\mathrm{R}$ 光と $\mathrm{R}+\mathrm{FR}$ 光の照射が，夏秋輪ギク “岩の白扇’ の花芽分化抑制に及ぼす影響

\begin{tabular}{|c|c|c|c|c|}
\hline & \multicolumn{2}{|c|}{ 葉数（枚） } & \multicolumn{2}{|c|}{ 草丈（cm） } \\
\hline & 消灯時 & 収穫時 & 消灯前 & 収穫時 \\
\hline$R$ 光照射区 & 29.7 & 37.4 & 67.2 & 91.0 \\
\hline R + FR 光照射区 & 29.5 & 43.2 & 68.1 & 99.6 \\
\hline $\mathrm{t}$ 検定 ${ }^{\mathrm{z}}$ & ns & $*$ & ns & $*$ \\
\hline
\end{tabular}

第 7 表 $\mathrm{R}$ 光と $\mathrm{R}+\mathrm{FR}$ 光の照射が, 秋輪ギク ‘新神 2’ の花 芽分化抑制に及ぼす影響

\begin{tabular}{ccccccc}
\hline \hline & \multicolumn{2}{c}{ 葉数 $($ 枚 $)$} & & \multicolumn{2}{c}{ 草丈 $(\mathrm{cm})$} \\
\cline { 2 - 3 } \cline { 5 - 6 } & 消灯時 & 収穫時 & & 消灯前 & 収穫時 \\
\hline $\mathrm{R}$ 光照射区 & 45.7 & 67.6 & & 75.4 & 113.2 \\
$\mathrm{R}+\mathrm{FR}$ 光照射区 & 45.0 & 67.4 & & 73.6 & 112.0 \\
\hline $\mathrm{t}$ 検定 ${ }^{\mathrm{z}}$ & $\mathrm{ns}$ & $\mathrm{ns}$ & $\mathrm{ns}$ & $\mathrm{ns}$ \\
\hline
\end{tabular}

${ }^{\mathrm{z}} \mathrm{ns}$ は $\mathrm{t}$ 検定による 5\%水準で有意差なし

くなった (第 4 表). 夏秋輪ギク “岩の白扇”に敃いて最 も花芽分化抑制効果が高い波長は 593 抢よび $630 \mathrm{~nm}$ 区で あった． $663 \mathrm{~nm}$ 区は 593，630 $\mathrm{nm}$ 区に対して明らかに抑 制効果が劣った. 516，684 㧊よび $705 \mathrm{~nm}$ の波長は抑制効 果が認められなかった。
2）秋輪ギク ‘新神 2’における波長と抑制効果（試験 2)

暗期中断光源の波長の違いによる花芽分化抑制効果は発 蕾日と開花時の展開葉数で判定した．すべての区で電照期 間中に発蕾が認められた。発蕾日は無処理区と $516 \mathrm{~nm}$ 区 が注涪同等で最も早く, 684 と $705 \mathrm{~nm}$ 区, 593, 663, $630 \mathrm{~nm}$ 区の順であった．展開葉数は無処理区が 39 枚と最も少な く, 以下各処理区の発蕾日の遅机に伴い葉数は増加し, $630 \mathrm{~nm}$ 区で約 60 枚と最も多くなった (第 5 表). 以上の結 果より秋輪ギク ‘新神 2’ に扔いて最も花芽分化抑制効果 が高い波長は $630 \mathrm{~nm}$ であった。これよりわずかに波長の 短い $593 \mathrm{~nm}$ 区打よびわずかに長い $663 \mathrm{~nm}$ は $630 \mathrm{~nm}$ に対 して明らかに抑制効果が劣った.さらに 684 抢よび $705 \mathrm{~nm}$ の波長でもわずかに抑制効果が認められた.

\section{R 光および $F R$ 光の組み合わせによる花芽分化抑制能力} の検討（試験 3，4）

花芽分化抑制効果を $\mathrm{R}$ 光 $644 \mathrm{~nm}$ 単照射区と $\mathrm{R}$ 光 $644 \mathrm{~nm}+$ FR 光 $732 \mathrm{~nm}$ の混合光照射区で比較したが，“岩の白扇’で は収穫時の葉数や草丈は, $R$ 光 $644 \mathrm{~nm}$ 単照射区に比べ $R$ 光 $644 \mathrm{~nm}+\mathrm{FR}$ 光 $732 \mathrm{~nm}$ の混合光照射区で有意に開花時の展 開葉数が多く, 草丈が高かった (第 6 表)。一方，“新神 $2 ’$ に打いては双方の展開葉数や草丈に有意な差は認められな かった (第 7 表). 以上の結果より $\mathrm{R}$ 光に FR 光を組み合わ せた影響は，秋ギク“新神 2’では認められなかったが，夏 秋ギク ‘岩の白扇’ ではFR 光を添加した方が花芽分化抑 制効果が高いことが明らかとなった.

\section{考察}

光周性花成のためには $\mathrm{R}$ 光，特に $630 \sim 660 \mathrm{~nm}$ 付近の 波長が効果が高いと報告されて括り（Borthwic ら，1948， 1952a; Parker ら，1946，1950)，キクの電照抑制栽培に捖い ても $\mathrm{R}$ 光が最も効果的であると考光られてきた（小西ら， 1990). 本試験ではピーク波長 $516 \mathrm{~nm}$ の緑色光〜ピーク波 長 $705 \mathrm{~nm}$ の FR 光まで 6 種類の電球形 LED ランプ光源を 供試し，秋ギクと夏秋ギクの花芽分化抑制効果の検証を 行った。 その結果，ピーク波長 593，630 扤よび $663 \mathrm{~nm}$ が 無電照抢よび他の波長と比べて，有意に花芽分化抑制効果 が高かった. 効果のあった波長のうち ‘新神 2’では $630 \mathrm{~nm}$ が， ‘岩の白扇’では $593 \sim 630 \mathrm{~nm}$ が最も効果が高かった. $663 \mathrm{~nm}$ については両品種ともに効果がやや低下寸る傾向 にあった。

フィトクロムを介した光情報伝達と暗期中断時の波長と の関係を考学る場合, フィトクロムの波長ごとの光化学変 換効率と $\mathrm{Pr}$ 型と $\mathrm{Pfr}$ 型の光平衡状態 $(\mathrm{Pfr} / \mathrm{Pr}+\mathrm{Pfr})$ を考慮 する必要がある。フィトクロムのP Pr 型とPfr 型は，それぞ れ光吸収スペクトルに応じた光化学変換作用スペクトルを 示す. Pr 型から Pfr 型への光化学変換効率は, $660 \mathrm{~nm}$ 付近 の波長域が最も高く, さらにこの波長域では Pr 型と Pfr 型 の光吸収スペクトルの重なりが小さく $\mathrm{Pfr} / \mathrm{Pr}+\mathrm{Pfr}$ の值も大 きいと見積もられる（Sager ら，1988）ため， $660 \mathrm{~nm}$ 付近 
が最も花芽分化抑制効果の高い波長域と推察される. しか し, 本試験の結果では, $660 \mathrm{~nm}$ よりも $630 \mathrm{~nm}$ 付近で花芽 分化抑制効果が高かった (第 4 表, 第 5 表)。同様の結果は 他のキク品種を用いても観察されている（大石ら，2010; 住 友ら, 2011). この要因として>ィトクロムと光の吸収スペ クトルが重なり合らクロロフィルの影響が考光られる。

Ohtani・Kumagai（1980）は，暗黑下で育成したクロロフィ ルを含まない短日性アオウキクサを用いて, FR 照射による 花成抑制の解除に及ぼす $612 \mathrm{~nm}$ 打よび $660 \mathrm{~nm}$ の R 光の影 響を緑色植物と比較して調べた結果, 黄化植物では $660 \mathrm{~nm}$ 付近の光照射の効果が最も高いのに対して, 緑色植物では $660 \mathrm{~nm}$ よりも短波長の $612 \mathrm{~nm}$ に効果がシフトすることが 示され，短日性アオウキクサの花成誘導に関わるフィトク ロム反応がクロロフィルなどの色素により遮蔽されること を明らかにした、インゲンマメの肧軸伸長抑制試験に扒い ても同様にフィトクロム反応がクロロフィルの影響を受け ることが示されている（Jose・Schafer, 1978）。これらのこ とより，キクの暗期中断時の波長と花芽分化抑制効果の関 係を考光る場合, フィトクロムの波長ごとの光化学变換効 率と Pr 型と Pfr 型との光平衡状態に加兄, 生体内に共存す るクロロフィルなどの色素の影響を考慮する必要があると いえる.

本試験での照射光量ではピーク波長 $516 \mathrm{~nm}$ の光に対す る花芽分化抑制効果は著しく低かった（第 $4 ， 5$ 表）。飽和 光量のもとでは, ピーク波長 $510 \mathrm{~nm}$ 付近 $680 \mathrm{~nm}$ 付近の 単色光下での $\mathrm{Pfr} / \mathrm{Pr}+\mathrm{Pfr}$ の值は 0.7 以上の比較的高い值を 示すが, $450 \mathrm{~nm} \sim 550 \mathrm{~nm}$ 付近の光では Pr 型から Pfr 型へ の光化学変換効率が著しく低い（Sager ら， 1988; Stutte, 2009）ため, 本試験での光照射量では花芽分化抑制効果が 十分でなかったと推察される.

暗期中断電照による花芽分化抑制効果を検討する場合, 気温や日照条件などの環境要因についても考慮する必要が ある，生産現場で秋ギクを栽培する場合に，光量不足によ る電照効果が問題になるのは, 季咲きに近い花芽分化に適 した温度や日照条件での作型であり，3 月出しのような低 温・寡日照条件では電照効果の問題が発生しにくいことが 知られている. 本研究に着手する際の予備検討において, “新神 $2 ’ 3$ 月出しの最低夜温 $10^{\circ} \mathrm{C}$ 条件下では, ピーク波 長 $516 \mathrm{~nm}$ の光照射（畧面での放射照度 $50 \mathrm{~mW} \cdot \mathrm{m}^{-2}$ ) でも 花芽分化抑制効果がみられた (データ省略)。これらのこと から，その効果は低いものの暗期中断による花成抑制に有 効な波長域は緑色光（ピーク波長 $516 \mathrm{~nm}$ ) 付近からはじ まっている可能性が考兄られる。

短日植物の花成反応に扮いては波長 $600 \sim 700 \mathrm{~nm}$ の R光 の暗期中断による花成抑制効果が, 波長 $735 \mathrm{~nm}$ 付近の FR 光により打ち消されることが知られている (Cathey・Borthwick, 1964）。それゆ光 FR 光を多く含む光源, 例光ば白熱 電球よりも FR 光の割合が少ない白色系の蛍光灯や LED ラ ンプが，キクなどの短日植物の電照用光源として有効であ
るとされてきた（Cathey・Borthwick, 1964; Accati-Garibaldi ら， 1977; 佐々木ら， 2006; 石倉ら， 2009）。一方, 渡辺ら （1996）は，秋ギク ‘秀芳の力’を用いて，白熱電球と $\mathrm{R}$ 光 LED と FR 光 LED を組み合わせた光源を比較し, FR 光 を多量に含む光源でも花芽分化抑制効果に差がないことを 報告している．鈴木ら（2011）は人工気象室で主明期に蛍 光灯を使用して，暗期中断に打ける光質の作用を調查した 結果, ‘岩の白扇’ の花芽分化が白熱電球または $\mathrm{R}$ 光 LED と FR 光 LED の組久合わせで強く抑制されていることを報 告している. 本試験で対象とした 2 品種のらち, 秋輪ギク “新神 2’ は, R 光に FR 光を加兄ても, 花芽分化抑制効果 に差は認められなかった（第 7 表）が，夏秋輪ギク “岩の 白扇’ は R 光に FR 光を加えることで, 明らかに花芽分化 抑制効果が高まった (第 6 表)。これらの結果をみると, キ クの花芽分化抑制に及ぼす FR 光の影響については, 従来 言われているよらな, FR 光が $\mathrm{R}$ 光の花芽分化抑制効果を 低下させる場合と，“秀芳の力’（渡辺ら，1996）や“新神 2’などのように FR 光が $\mathrm{R}$ 光の花芽分化抑制効果に影響し ない場合，そして ‘岩の白扇”のような FR 光が $\mathrm{R}$ 光の花 芽分化抑制効果を高める場合に類別される可能性が考兄ら れる。 ‘岩の白扇’でR 光に FR 光を加えることによる花芽 分化抑制効果が高まる原因については明らかではない、イ ネの暗期中断による花芽分化抑制では, phyB が重要な役割 を担うことが示されている（Ishikawaら，2005)。キクの暗 期中断に上る花芽分化抑制についても R/FR 可逆反応がみ られる (Cathey・Borthwick, 1964)。このR/FR 可逆反応は, phyB を介した低光量反応の特徵のひとつ（長谷, 2001）で あると考光られて扣り，キクの花芽分化抑制についても phyB を介した低光量反応が関与していると推察される. し かし, $\mathrm{R}$ 光に FR 光を加えることで効果が高くなることは, $\mathrm{R} / \mathrm{FR}$ 可逆反応が特徵である低光量反応では説明がつかな い.キク栽培では，一般的に暗期中断電照時間は $2 \sim 5$ 時 間であり, 本試験でも 5 時間と長時間の電照を行っている ことから，“岩の白扇’の事例のように FR 光が $\mathrm{R}$ 光の花芽 分化抑制効果を高める場合, phyA が重要な役割を担う FR 光による高照射反応 (HIR-FR) が関与している可能性もあ るが，詳細な機構の解明については今後の課題である.

現在，白熱電球の代替光源として LED が注目されてお り，本試験の結果をもとに電照効果の高い波長域の LED チップを使用した光源の普及が望まれる. 電照による花芽 分化抑制については，波長以外飞も電照の時間帯や品種間 差, さらに気温, 日射量などの環境要因も考慮する必要が あり，そ机らの要因も併せて解明していくことで，効率的 な電照栽培につながると考えている.

\section{摘 要}

秋輪ギク ‘新神 2’打よび夏秋輪ギク ‘岩の白扇’を用 いて，花芽分化抑制に招ける光源の波長と抑制効果につい て検証を行った. 光源は電球形 LED ランプを用いて, 光源 
ピーク波長実測值 516，593，630，663，684 および $705 \mathrm{~nm}$ の 6 種類を供試した. その結果, ‘新神 2’および ‘岩の白 扇’ともにピーク波長 593，630 および $663 \mathrm{~nm}$ が抑制効果 が認められ，最も抑制効果が高かったのは ‘新神 2’では $630 \mathrm{~nm}$ ，“岩の白扇’では，593 および $630 \mathrm{~nm}$ であった.

また ‘新神 2’および ‘岩の白扇’を用いて, 暗期中断 光源を $\mathrm{R}$ 光単照射と $\mathrm{R}$ 光 $+F R$ 光の混合光とで花芽分化抑 制効果を比較したところ, ‘新神2’ではR単色光とR光 $+\mathrm{FR}$ 光の混合光に花芽分化抑制効果の差は認められなかった が, ‘岩の白扇' では $\mathrm{R}$ 単色光よりも $\mathrm{R}$ 光 $+\mathrm{FR}$ 光の混合光 が抑制効果が高かった。

\section{引用文献}

Accati-Garibaldi, E., A. M. Kofranek and R. M. Sachs. 1977. Relative efficiency of fluorescent and incandescent lamps in inhibition flower induction in Chrysanthemum morofolium 'Albaltross'. Acta Hortic. 68: 51-58.

Borthwick, H. A., S. B. Hendricks and M. W. Parker. 1948. Action spectrum for photoperiodic control of floral initiation of a long-day plant, wintex barley (Hordeum vulgare). Botan. Gaz. 110: 103-118.

Borthwick, H. A., S. B. Hendricks and M. W. Parker. 1952a. The reaction controlling floral initiation. Proc. Natl. Acad. Sci. USA. 38: 929-934.

Borthwick, H. A., S. B. Hendricks, M. W. Parker, E. H. Tool and V. K. Toole. 1952b. Reversible photoreaction controlling seed germination. Proc. Natl. Acad. Sci. USA. 38: 662-663.

Cathey, H. M. and H. A. Borthwick. 1964. Significance of dark reversion of phytochrome in flowering of Chrysanthemum morifolium. Botan. Gaz. 125: 232-236.

久松 完. 2011. 電照を用いた花き類の開花調節技術. 耕と園芸. 66(2): 52-58.

Ishikawa, R., S. Tamaki, S. Yokoi, N. Inagaki, T. Shinomura, M. Takano and K. Shimamoto. 2005. Suppression of the floral activator $H d 3 a$ is the principal cause of the night break effect in rice. Plant Cell 17: 3326-3336.

石倉 聡・梶原真二・原田秀人. 2009. キクの電照抑制栽 培に用いる白熱電球代替光源としての電球形蛍光ラン プおよびLEDの光エネルギー特性と開花抑制効果. 広 島総研農技七研報. 84: 1-6.

石倉 聡 - 平間淳司 - 野村昌史 - 山下真一 - 東浦 優 - 岩 井豊通・二井清友・山中正仁. 2010. 黄色 LED パルス 光を用いた秋ギクの害虫防除光源装置の開発一開花の 遅延を回避できる光照射技術一. 植物環境工学. 22 : 167-174.

Jose, A. M. and E. Schafer. 1978. Distorted phytochrome action spectra in green plants. Planta 138: 25-28.

小西国義・今西英雄・五井正憲. 1990. 花卉の開花調節 p. 53. 養賢堂. 東京.

長谷あきら．2001．フィトクロム研究がたどってきた道. p. 24-38. 和田正三・徳富 哲・長谷あきら・長谷部光 泰編. 細胞工学シリーズ 16 「植物の光センシング」. 秀 潤社. 東京.

永吉実孝・上野敬一郎・今給黎征郎・郡山啓作・吉水竜次・ 南 公宗・田中見佳・田中 昭・長谷純宏・田中 淳. 2010. 品種登録 キク 品種名「新神 $2 」$ 品種登録番 号 第19096号.

大石一史・新井 聡・ 犬伏加恵・中村恵章. 2010. キクの 花芽分化抑制に有効な LED の波長，および花芽分化抑 制効果に及ぼす影響. 園学研.9(別2)：545.

Ohtani, T. and T. Kumagai. 1980. Spectral sensitivity of the flowering response in green and etiolated Lemna paucicostata T-101. Plant Cell Physiol. 21: 1335-1338.

Parker, M. W., S. B. Hendricks and H. A. Borthwick. 1950. Action spectrum for the photoperiodic control of floral initiation of the long-day plant Hyoscyamus niger. Botan. Gaz. 111: 242-252.

Parker, M. W., S. B. Hendricks, H. A. Borthwick and N. J. Scully. 1946. Action spectrum for the photoperiodic control of floral initiation of short-day plants. Botan. Gaz. 108: 126.

Sager, J. C., W. O. Smith, J. L. Edwards and K. L. Cyr. 1988. The use of spectral data to determine photosynthetic efficiency and phytochrome photoequilibria. Trans. Amer. Soc. Agr. Eng. 31: 1882-1889.

佐々木 厚・遠藤柳子・森山厳與. 2006. 秋ギク型スプレー ギク栽培における電球色電球形蛍光ランプの利用と経 済性. 宮城農園総研研報. 76: 52-61.

Stutte, G. W. 2009. Light-emitting diodes for manipulating the phytochrome apparatus. HortScience 44: 231-234.

住友克彦・樋口洋平 - 小田 篤 - 宮前治加 - 山田 真・石 渡正紀・久松 完. 2011. 暗期中断によるキクの花成 および FT 様遺伝子発現抑制における分光感度. 園学 研. 10 (別 2) : 251.

鈴木健太・廖 易・庄 得鳳・福井博一・嶋津光鑑. 2011 . 開花時期の異なるキク 2 品種（“神馬”・ ‘岩の白扇”） の花芽分化および成長に対する暗期中断処理時の光質 の影響. 日本生物環境工学会. 2011. 札幌大会講演要 旨 : 106-107.

渡辺博之・河合成典・吉野 徹・田中史宏. 1996. LEDを 光源とした植物栽培. (第 5 報) 秋ギク電照栽培におけ る遠赤色光の添加効果. 園学雑. 65 (別2)：568-569. 